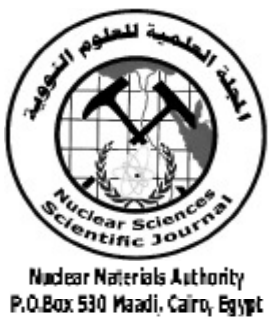

ISSN 2314-5609

Nuclear Sciences Scientific Journal vol. 4, p 1-19

2015

\title{
STUDIES ON FERRUGINATION IN GABAL AGIB RING COMPLEX, SOUTH EASTERN DESERT, EGYPT
}

\author{
MOHAMOUD M. HASSAAN, ADEL H. EL-AFANDY ${ }^{1}$, HATEM M. EL-DESOKY, \\ HASSAN M. ASRAN ${ }^{1}$ and OMAR A. SOLIMAN ${ }^{2}$ \\ Geology Dept.,Fac. Science, Al-Azhar Univ; ${ }^{1}$ Nuclear Materials Authority, Cairo; ${ }^{2}$ Raw material engineer, \\ Emirates steel, UAE.
}

\begin{abstract}
.
The present work deals with the ferrugination of Agib Ring Complex hosted by granites, Southeastern Desert Egypt. The studied Agib Ring Complex comprises well developed outer ring of alkali rhyolite porphyry and a quartz syenite core. Trachytes and their pyroclastic equivalents, forming roof pendants and rafts, represent the remnants of volcanic cone. The rock units of Agib ring complex are peralkaline formed in within plate tectonic setting. The quartz syenite consists essentially of perthitic orthoclase, antiperthitic plagioclase and quartz with relatively minor alkaline ferromagnesian minerals. The trachyandesites are generally porphyritic almost holocrystalline and occasionally hyalopilitic with phenocrysts of plagioclase, hornblende, chlorite, epidote, and quartz. The rhyolites are porphyritic holocrystalline to hypocrystalline with aphanitic matrix. The pyroclastics are very fine-grained groundmass, enclosing subangular to subrounded lithic clasts within the lapilli size. The host alkali feldspar granite is composed of antiperthitic plagioclase, perthitic orthoclase, hornblende, arfvedsonite, aegirine and quartz. Intense ferrugination is recorded in the rock units of Agib ring complex and the host rocks in the form of disseminated crystals or skeleton like crystals, filling the fractures, replacing the rock forming minerals and staining. The recorded ore minerals are hematite, magnetite martite, goethite and ilmenite forming the hydrothermal iron mineralization.
\end{abstract}

\section{INTRODUCTION}

The present studies deal with geology, mineralogy, petrography and geochemistry of ferrugination recorded in Gabal Agib East-Um Hibal district, Southeast Aswan,

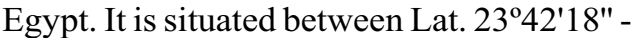
$23^{\circ} 43^{\prime} 43^{\prime \prime} \mathrm{N}$ and Long. $33^{\circ} 16^{\prime} 31^{\prime \prime}-33^{\circ} 18^{\prime} 37^{\prime \prime}$ E reached through the Aswan Wadi Allaqi asphaltic road (Fig. 1). The studied area comprises different types of topographic features. Several wide wadis (dry valleys) and their tributaries dissect the exposed rock units.
The Um Hibal-Gabal Agib district is covered by the Pan-African late Proterozoic rock units chiefly granites, ferruginated ring complex that cut by various types of faults and joints. The chronological sequence following El-Afandy (2003) is as follows:-

-Granitic dykes (Youngest)

- Rhyolites and pyroclastics

-Gabal Agib Ring Complex

-Sandstones of Nubia facies (Timsah and Um Barmiel Fms.) 


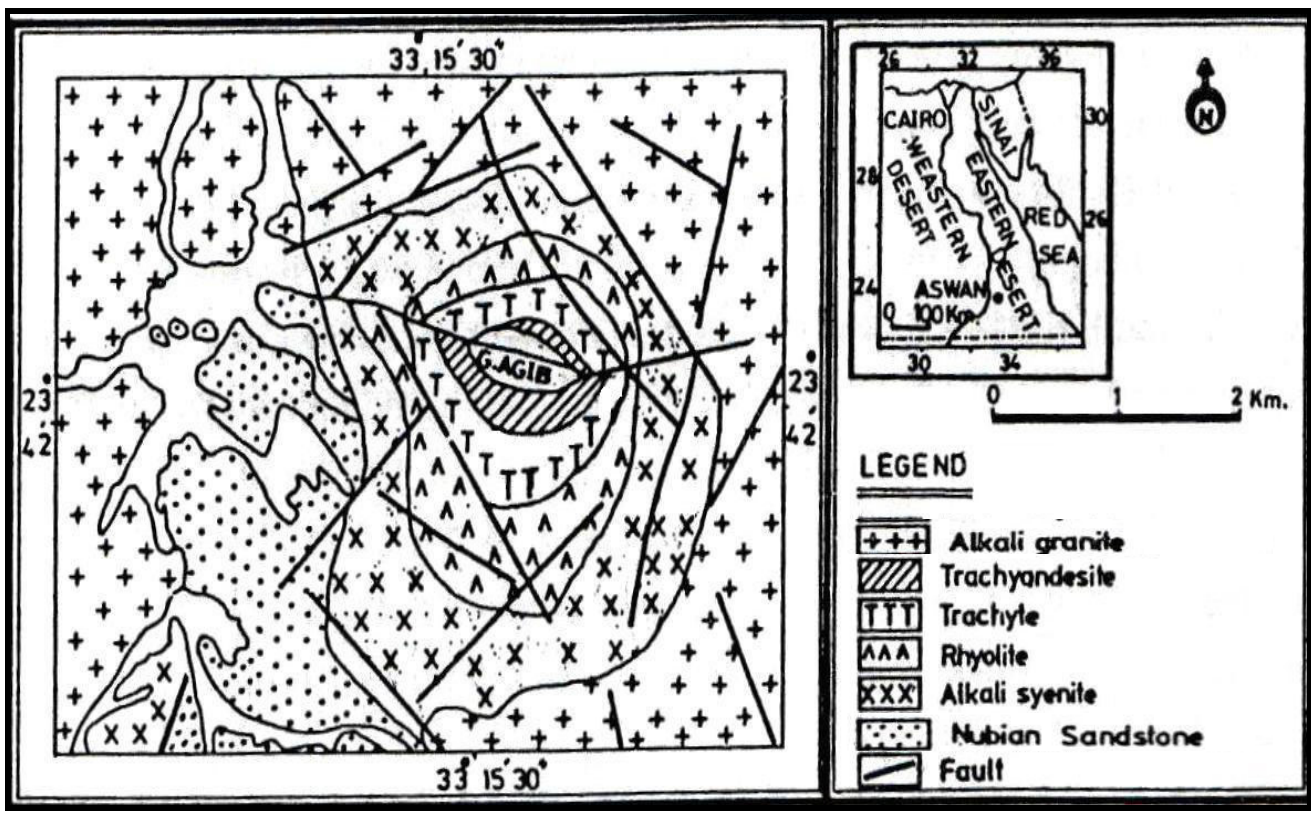

Fig.1: Detailed geologic map of Gabal Agib ring complex and the field relations between the different rock types (El-Amin, 1998 and El-Afandy, 2003)

-Basement rocks (BUH-monzonitic gran

ites)

(Oldest)

The mineral composition of the iron ore minerals and country rocks are studied using both the ore microscope, X-ray diffraction (XRD) and scanning electron microscope (SEM) techniques. Qualitative analysis is performed on hematite, ilmenite, goethite and magnetite using a SEM with (EDS Link AN 10000 System). These analyses were carried out in the Central Laboratory of the Nuclear Materials Authority (NMA). Forty representative samples are collected. Of these, 25 prepared thin-polished sections are studied to identify the mineral constituents, and textures of iron ore minerals. These studies dealt as well with petrographic description of the various rock units. Chemical analysis of 25 representative samples are carried out for major oxides and trace elements in NMA \&
EGSMA laboratories for petrochemical characterization, magma type, and tectonic setting of the rock units forming Agib ring complex.

\section{GEOLOGIC SETTING AND PETROGRAPHY}

The chief part of Agib ring complex occurs as lava flows in the northern boundaries of Gabal Agib. The Gabal Agib ring complex comprises mainly granite stock cutting syenite, trachyandesite and trachyte. Agib ring complex porphyritic dykes intersect the trachyte only. The investigated ring complex is emplaced into the Bir Um Hibal batholith. It is distinguished from its country rocks by its lighter colors, where the margin of this ring complex consists of albitized leucocratic medium-to coarse-grained monzonite. The surrounding Bir Um Hibal monzonitic granites are mesocratic, dark red and silicified monzonite unconformably overlain by Nubian sandstone represented by the Timsah and Um Barmil formations. 


\section{Quartz Syenite}

The coarse-grained highly hematitic jointed quartz syenites are widely distributed in the northern and southern parts of Gabal Agib ring complex. They are buff in color and scarcely brick red shades due to iron oxides staining. It consists essentially of perthitic orthoclase, antiperthitic plagioclase and quartz with relatively minor aegirine-augite and arfvedsonite. Allanite, apatite, zircon and hornblende are the main alteration accessory minerals. Tourmalinization, albitization and hematization are the main alteration processes affecting these highly fractured rocks.

Perthitic orthoclase is coarse to very coarse, subhedral to euhedral elongated prismatic crystals, slightly altered to sericite and kaolinite (Fig.2). The antiperthitic plagioclase is euhedral to subhedral prismatic crystals, very common developed Carlsbad twinning with variable width moderately altered to saussurite and embayed by potash feldspars and quartz (Fig.3).

The aegirine-augite occurs as subhedral to euhedral green hydrothermal crystals, patchy or irregular shreds and remnants within the pseudomorphic arfvedsonite (Fig.2) and partially to totally altered to hornblende.

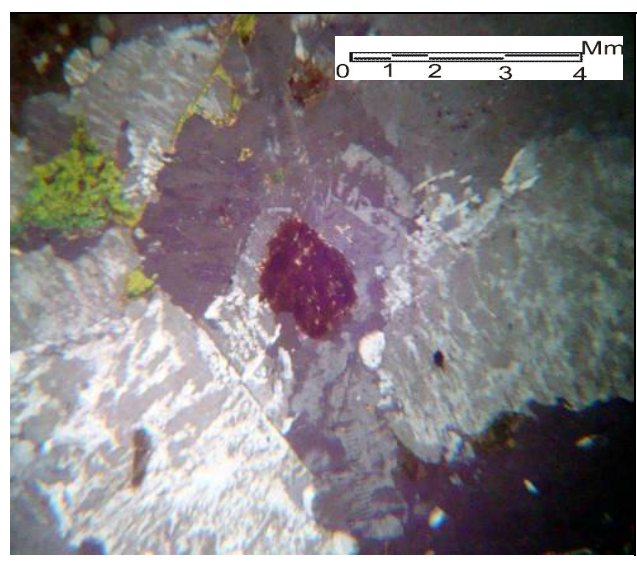

Fig.2:Photomicrograph showing perthitic orthoclase and yellowish green arfvedsonite in quartz syenite, XPL
The arfivedsonite is alteration product of euhedral to subhedral crystals of pyroxene green in color and two sets of cleavage (Fig.2). It forms fine aggregates. Hornblende is subhedral crystals associate with the arfvedsonite (Fig. 3).

Quartz is subhedral to anhedral crystals fine to coarse-grained, possess wavy extinction and corrosive action with the surrounding feldspar crystals. Zircon, the most abundant accessory mineral occurs as small short prismatic crystals embedded in feldspars and quartz, fine, euhedral crystals with overgrowth zonation. Epidote forms granular aggregates and anhedral crystals associated with the orthoclase and plagioclase. Allanite subhedral crystals exist.

Tourmaline is perfect euhedral, columnar and bipyramidal prismatic with hexagonal cross-section, fractured crystals (Fig.4). Most of these crystals are of homogeneous color.

Hematite as disseminated crystals and as skeletal like crystals exist filling the micro fractures (Figs.5-9). The X-ray Diffraction analysis of two samples identified quartz, albite, microcline and hematite.

\section{Porphyritic Andesites}

Andesite dykes or occasionally as small

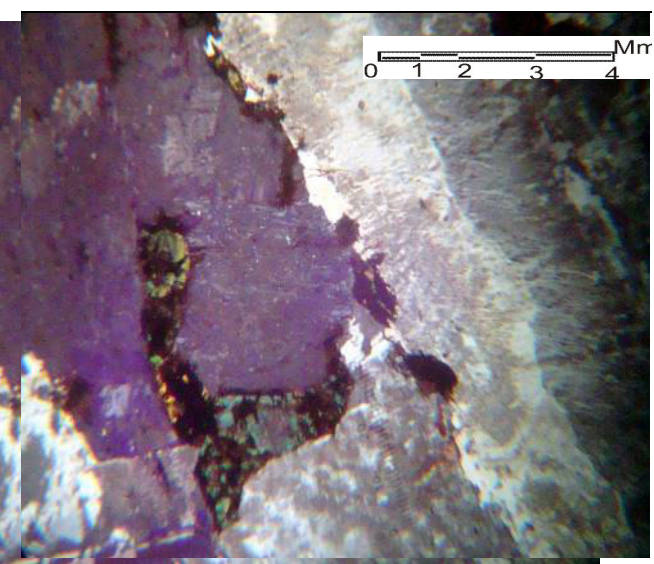

Fig.3:Photomicrograph showing hematite filling the contacts of quartz and albite crystals in quartz syenite, XPL 


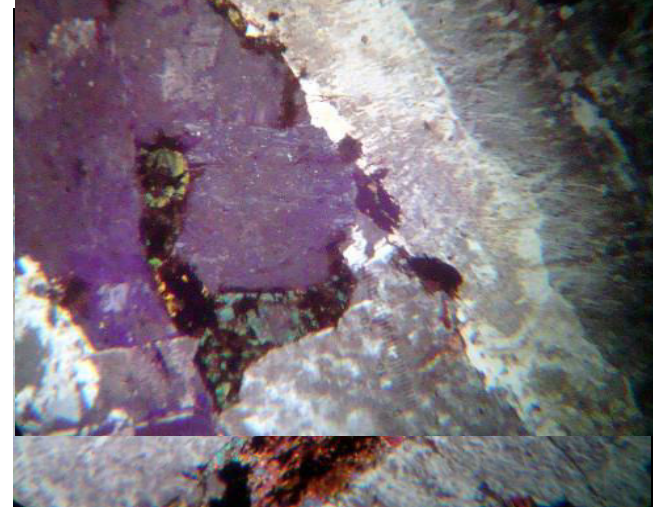

Fig.4: Photomicrograph showing hematitized pyroxene enclosed in perthitic orthoclase, quartz syenite, XPL

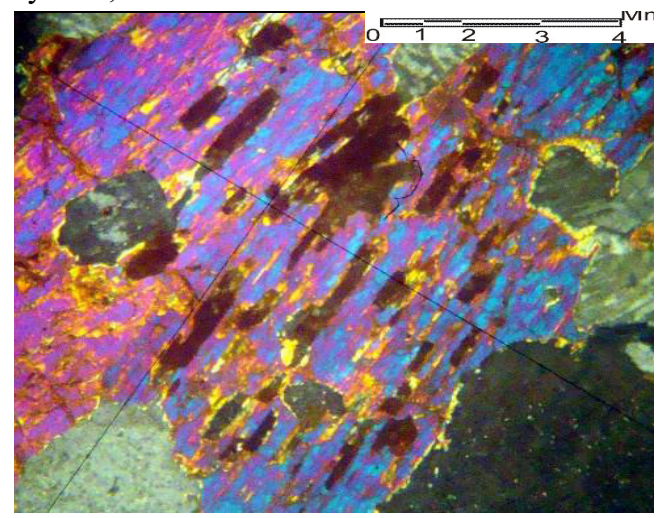

Fig.5:Photomicrograph showing large porphyritic pyroxene incorporated by iron ore minerals, quartz syenite, XPL

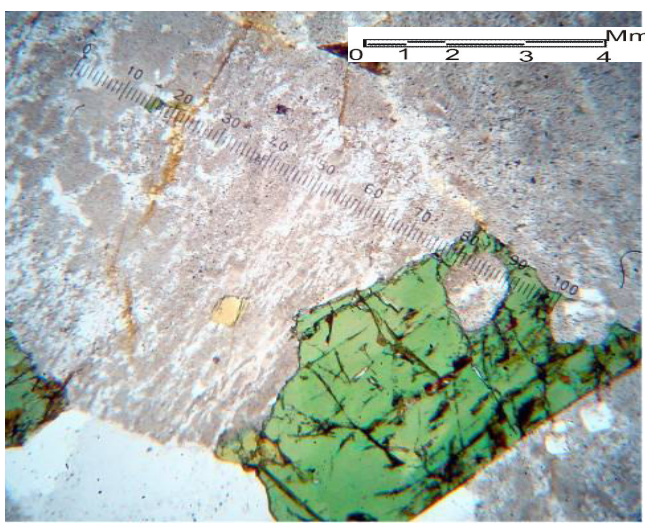

Fig.6:Photomicrograph showing high relief, two sets of cleavage of arfvedsonite filled by iron oxides, quartz syenite, PPL

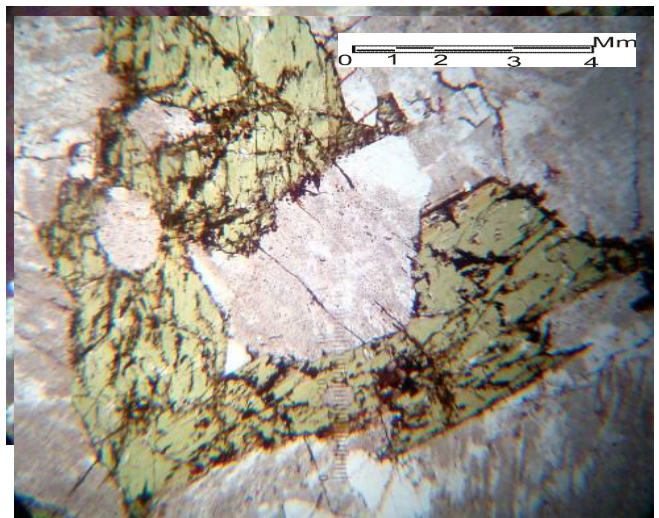

Fig.7:Photomicrograph showing hornblende filled by iron oxides in microcleavge, quartz syenite, PPL

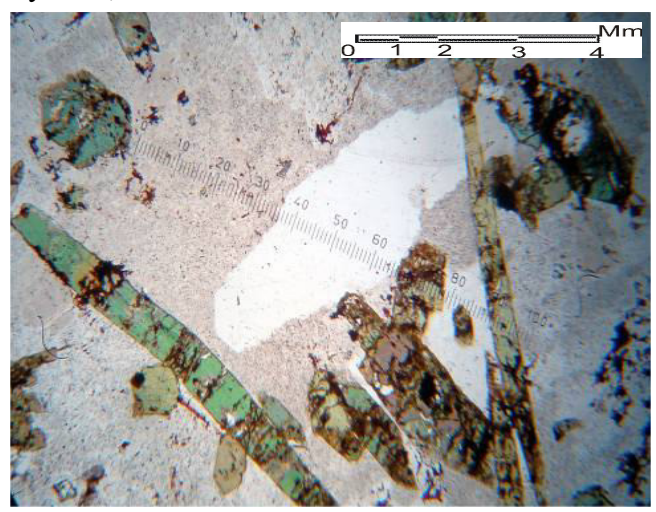

Fig.8:Photomicrograph showing perfect euhedral, columnar crystals of tourmaline with a cloudy very fine kaolinite and cracks filled by iron oxides, quartz syenite, PPL

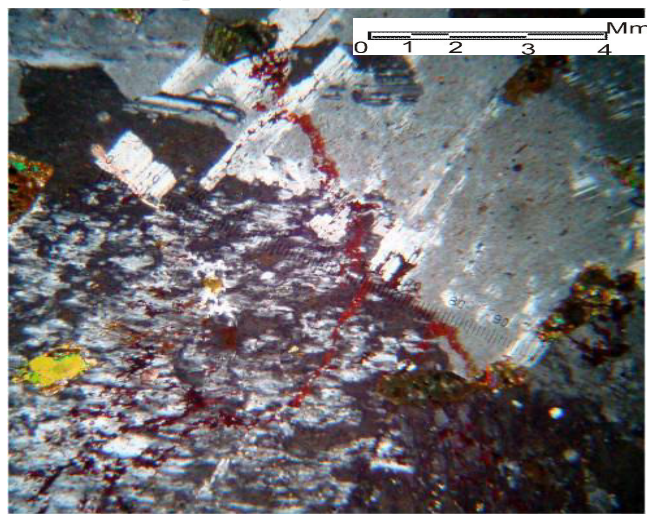

Fig.9: Photomicrograph showing microfractures filled by hematite in perthite texture, quartz syenite, XPL 


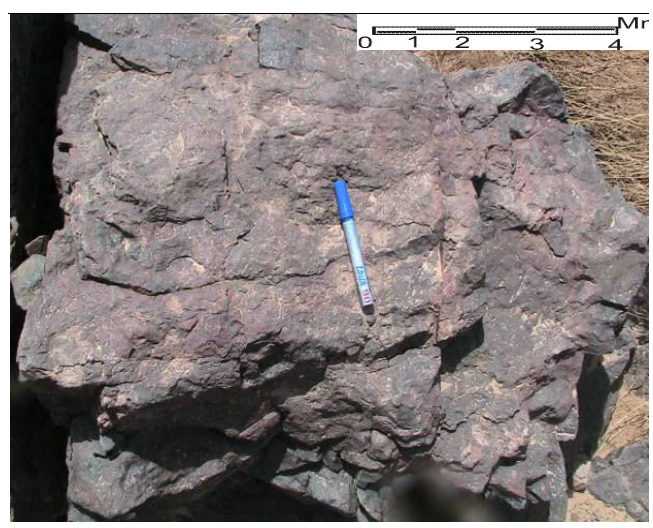

Fig.10: Photograph showing general view for the high ferruginated reddish gray trachyandesite dyke

bodies are of limited distribution in the area and of vary extension (Fig.10). Two dykes located to the south and east of Gabal Agib are cutting the granites.

Petrographically, these rocks are almost holocrystalline and occasionally hyalopilitic. They are fine to medium-grained, generally porphyritic (Fig. 11) with phenocrysts of plagioclase, hornblende set in a groundmass of plagioclase, hornblende, chlorite, epidote, quartz and iron ore minerals. The plagioclase phenocrysts vary from oligoclase to andesine in composition. It occurs as euhedral to subhedral, prismatic to lath-shaped crystals (Fig. 12). The small crystals are sometimes oriented subparallel to the phenocrysts.

The amphiboles are represented by hornblende and tremolite-actinolite. Hornblende occurs as subhedral fine crystals showing strong pleochroism from pale brown to dark brown. It is associated with plagioclase and partly altered to tremolite and chlorite (Fig.13).

Quartz occurs as fine-to medium-grained, anhedral to subhedral crystal aggregates filling the interstitial spaces between other crystals. Chlorite and epidote occur as minute inclusions in the other minerals.

Iron minerals occasionally form irregular grains and filling microfractures in the plagio-

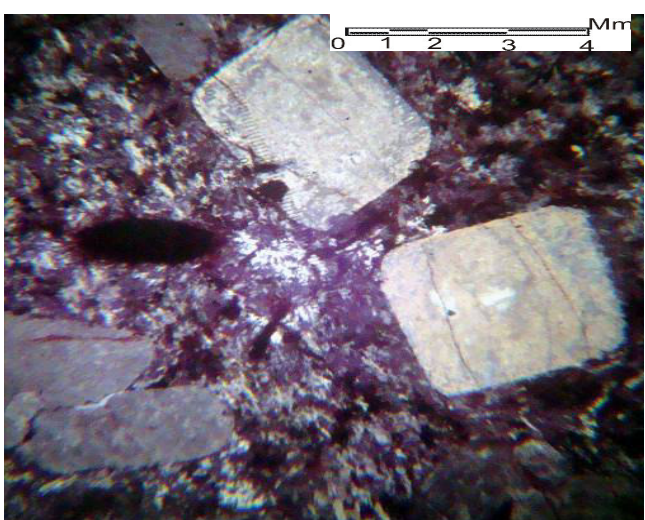

Fig.11:Photomicrograph showing porphyritic texture in trachyandesite, XPL

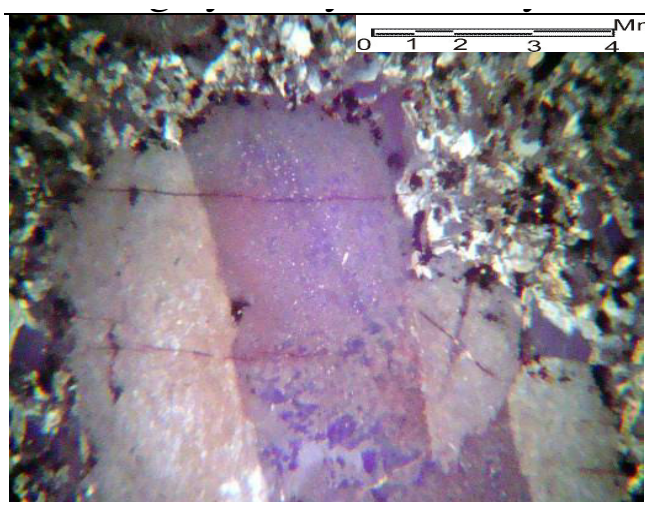

Fig.12:Photomicrograph showing Carlsbad twinning in plagioclase, trachyandesite, XPL

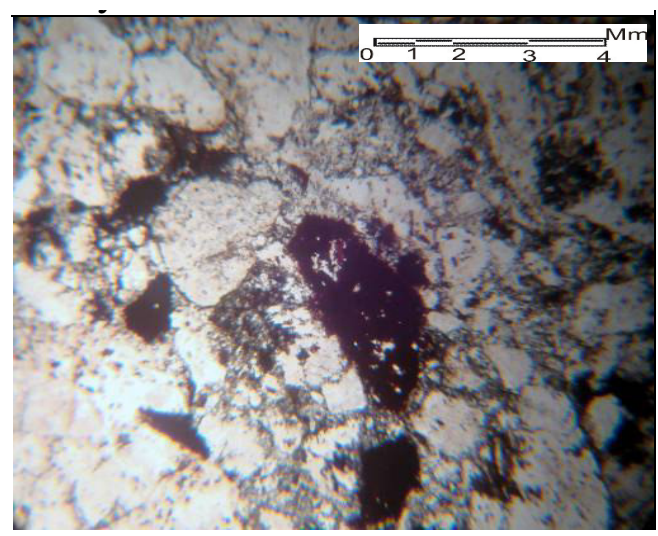

Fig.13:Photomicrograph showing hornblende stained by hematite, trachyandesite, PPL 


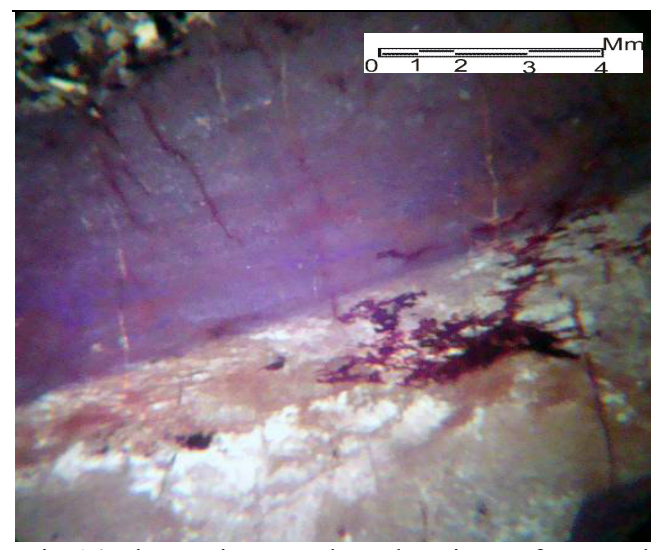

Fig.14:Photomicrograph showing fractured plagioclase crystal filled by hematite, trachyandesite, XPL

clase and in groundmass; occasionally show preferred orientation (Fig.14).

\section{Trachy-andesite}

The trachy-andesites are lava flows, vein-like, pod-like or lens- shaped bodies of limited distribution in the studied district especially the central part of Gabal Agib ring complex (Fig.10). It is composed of fine to very fine crystals of sanidine, orthoclase and plagioclase.

Petrographically, the trachy-andesites are composed of plagioclases, amphiboles and pyroxenes. The accessory minerals are opaque minerals in addition to primary and secondary quartz. Plagioclase occurs as finegrained subhedral tabular crystals and fine laths oriented with their longer dimensions parallel to the direction of flows, broken and saussuritized (Fig.15)

Hornblende is anhedral crystals highly altered to chlorite. Pyroxene crystals of minute size occur scattered in groundmass and form very minute microlites.

Zircon usually occurs as inclusions of minute crystals of short prismatic habit. Quartz exists as primary and secondary generations. The primary quartz is scarcely found and forms irregular interstitial silica like patches. Fair amount of the secondary quartz occasion-

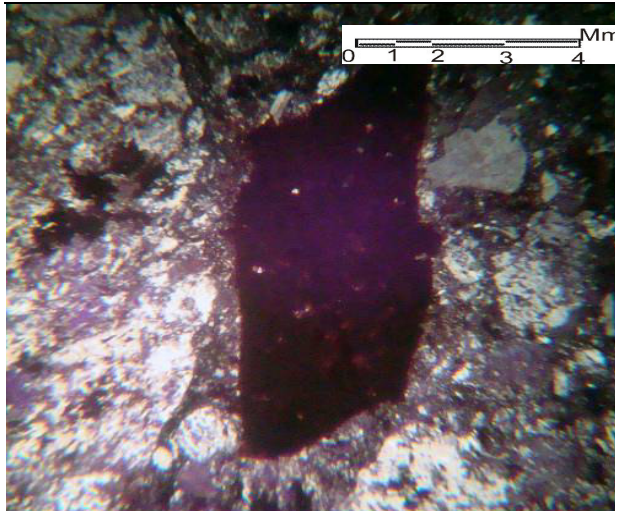

Fig.15:Photomicrograph showing large phenocryst of hematite and fine-grained quartz in trachyandesite, XPL

ally exists in subordinate and sporadic anhedral interstitial grains. It invades and corrodes the other constituents (Fig.15). Chlorite (penninite) and expelled iron oxides are common breakdown products. These are developed along the cracks or completely replace it.

Iron ore minerals are present as anhedral crystals. They commonly exist filling the interstitial spaces, as granules filling micro fractures forming micro veinlets (Figs. 16-18). The X-ray diffraction analysis of two samples recorded hematite, quartz, albite, microcline and leucosphenite.

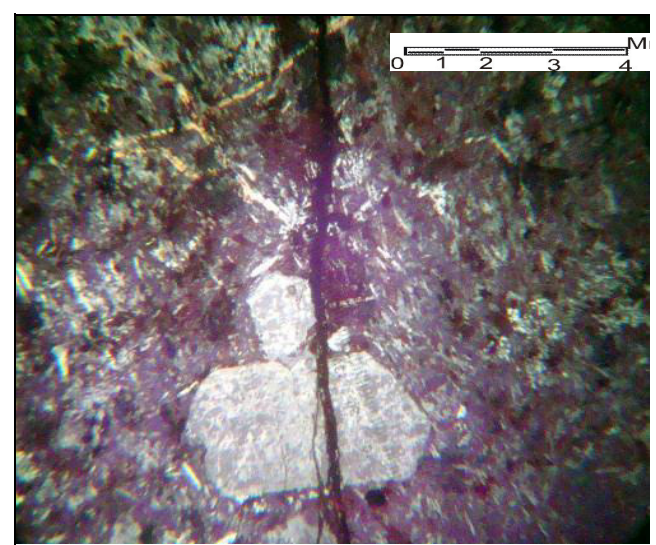

Fig.16: Photomicrograph showing plagioclase crystals fractured filled by hematite in trachyandesite, XPL 


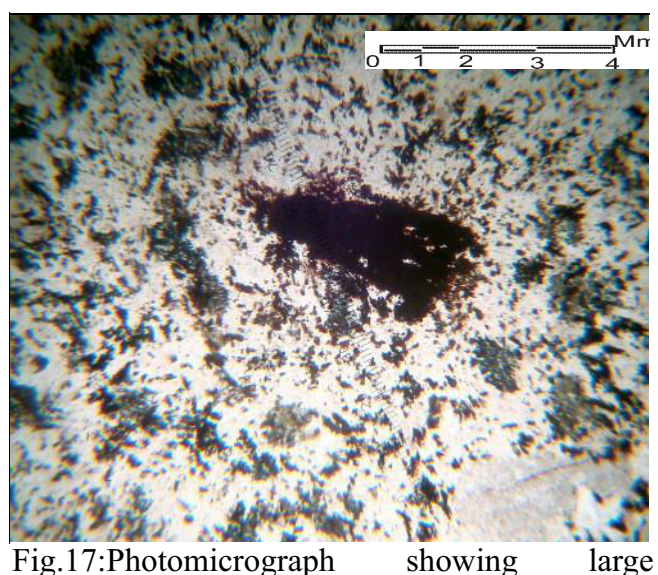
hematitic ferrugination, fine-grained pyroxene in trachyandesite, PPL

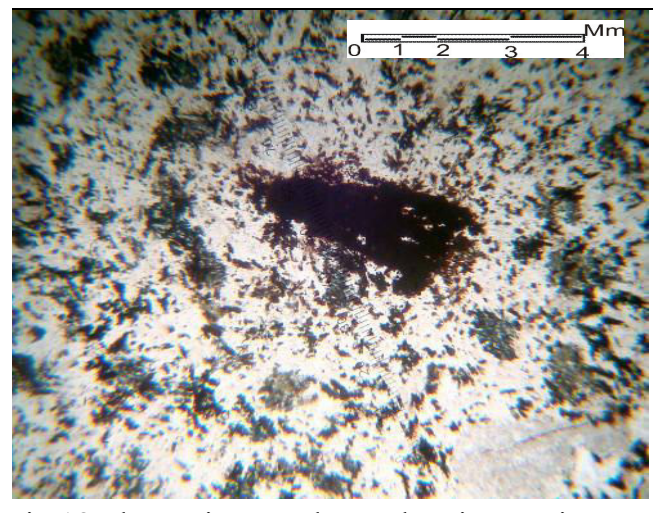

Fig.18:Photomicrograph showing intense hematitic ferrugination, fine-grained pyroxene in trachyandesite, PPL

\section{Volcanics}

Thick incomplete ring-dike of porphyritic rhyolite (Fig.1) dissects the quartz syenite with sharp contact. The porphyritic rhyolite dyke is extruded along a southern ring fracture forming the ring dyke of Gabal Agib ring complex (El-Afandy, 2003, and Agha, 2007).

These rocks are petrographically holocrystalline to hypocrystalline with aphanitic matrix composed of quartz, alkali feldspar and sanidine. This rock type exhibits porphyritic texture (Fig.19).

These rocks are composed of quartz and

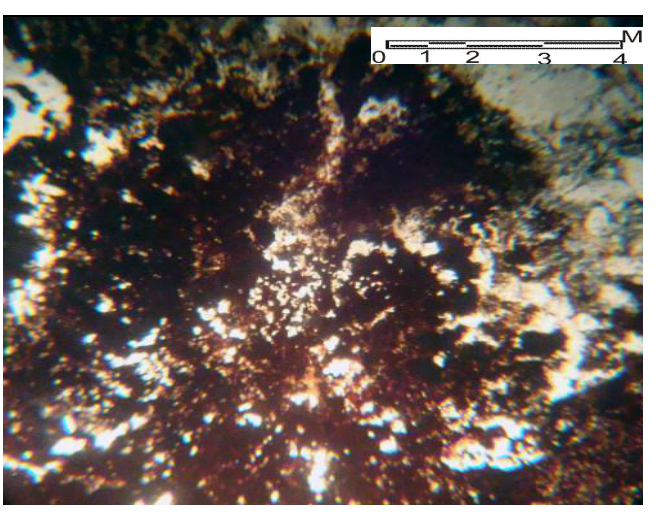

Fig.19: Photomicrograph showing patches of hematite in trachyte, PPL

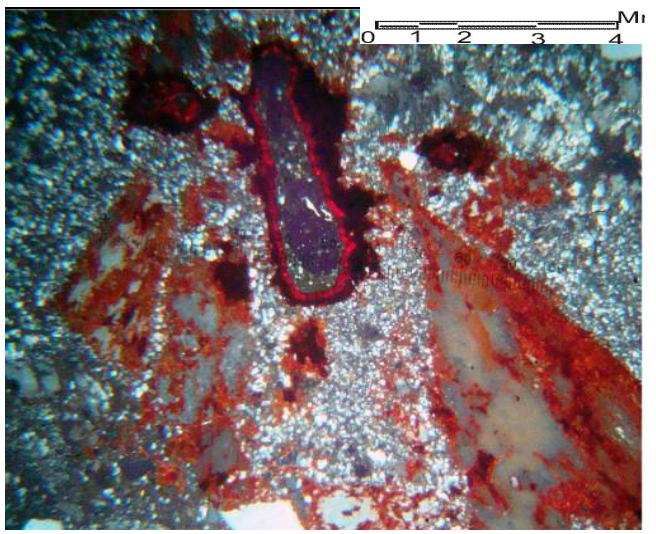

Fig.20 : Photomicrograph showing hematite filling intergranular spaces in rhyolite, XPL

sanidine phenocrysts in partially devitrified glassy groundmass totally ferruginated with hematite. Rare fragmented plagioclase exists. All the mafics are altered to opaques by action of alteration process (Fig.20).

Quartz crystals are more fragmented than the feldspars. The quartz phenocrysts are commonly corroded by the groundmass and show embayment texture. This rock contains rounded small xenoliths of quartzite, most probably after Nubia sandstone. Quartz crystals exist as phenocrysts and in groundmass.

The phenocrysts form more or less subhedral bipyramidal crystals (Fig.21). Many of these phenocrysts are highly crushed in situ. 


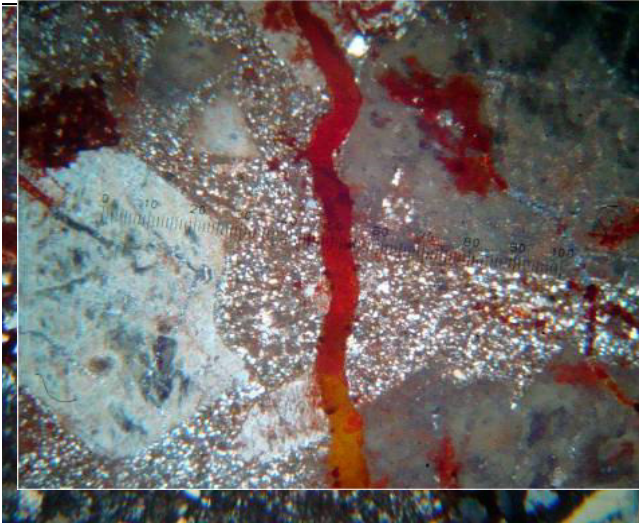

Fig.21:Photomicrograph showing quartz phenocrysts corroded by hematite filling the intergranular spaces in porphyritic rhyolite, XPL

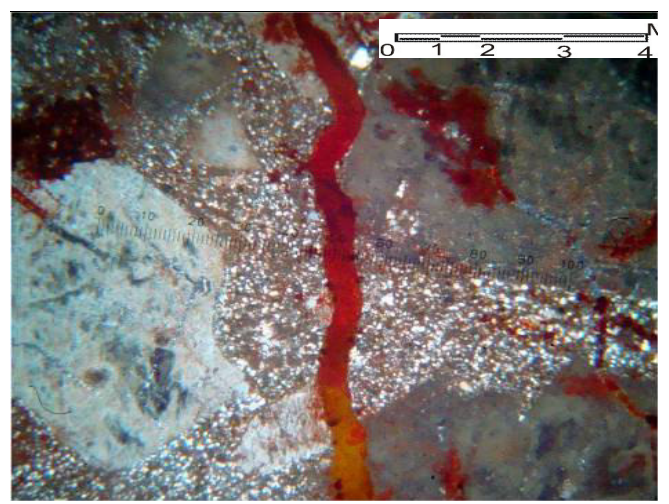

Fig.22:Photomicrograph showing prismatic sanidine crystals and fracture filled with hematite, porphyritic rhyolite, $\mathrm{XpL}$

Sanidine phenocrysts are subhedral to euhedral, prismatic or bipyramidal prismatic crystals, show transverse cracks filled with hematite (Fig. 22). All the crystals are kaolinized and stained by hematite contributing their reddish brown colors.

Mafic minerals are commonly fine-to medium-grained, anhedral crystals completely altered to opaque minerals represented chiefly by brown to black color iron oxides (Figs.22 $\& 23)$. These opaques occur either as finegrained granular aggregates or medium-to

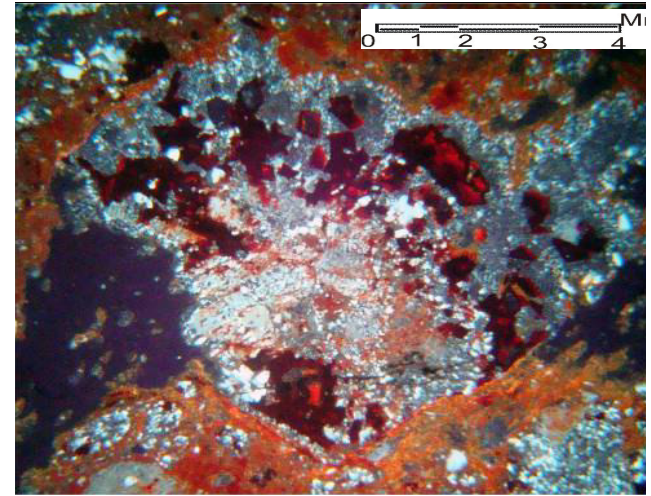

Fig.23:Photomicrograph showing hematite filling intergranular, spaces in porphyritic rhyolite, XPL

coarse-grained anhedral to subhedral crystals enclosed within quartz and alkali feldspar crystals.

Two X-ray diffraction analyses recorded quartz, albite, microcline, hematite and kaolinite.

\section{The Pyroclastics (Agglomerates)}

They are recorded mainly in Gabal Agib at the contact between the porphyritic rhyolite and the granitic stock. Petrographically, these pyroclastics are very fine-grained groundmass, enclosing fragments mainly of subangular to subrounded lithic clasts within the lapilli size. Occasionally, the groundmass shows parallel flow texture becomes laminated. This process also affected the lithic fragments leading also to its lamination. According to Agha (2007), these laminations produced after their extrusion may be due to hot gases fluidization. The lithic lapillis are subangular to subrounded fragments of trachytic, andesitic and rhyolitic composition, in addition to fine-grained sandstone fragments. Iron ore minerals are recorded filling the microfractures and the intergranular spaces (Figs. 24-28).

\section{Alkali Granites}

These granites are in the form of sheets, dykes and irregular elongated masses cutting the porphyritic rhyolite and the older rocks. It is mainly encountered at the southeastern and 


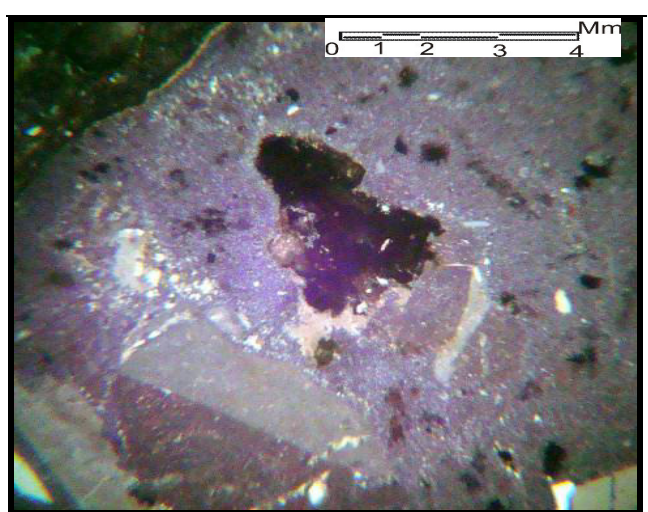

Fig.24:Photomicrograph of pyroclastics showing rock fragments which consist of orthoclase quartz and hematite fillings, lithic tuffs, XPL

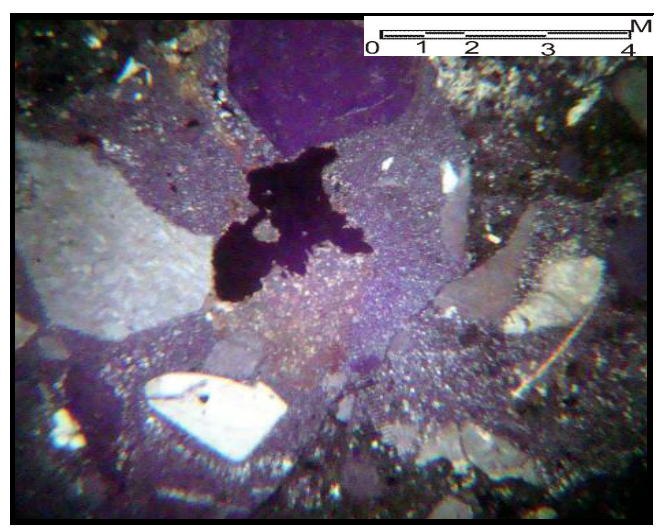

Fig.25:Photomicrograph showing agglomerate bearing hematite, lithic tuffs, XPL

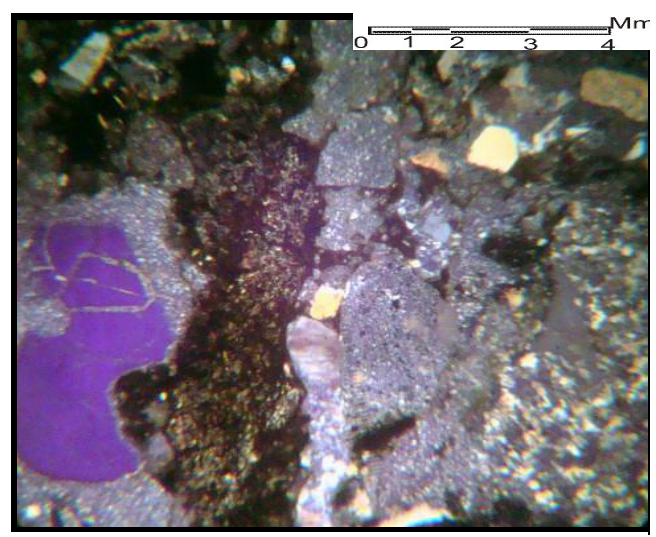

Fig.26 : Photomicrograph showing hematite, lithic tuffs, XPL

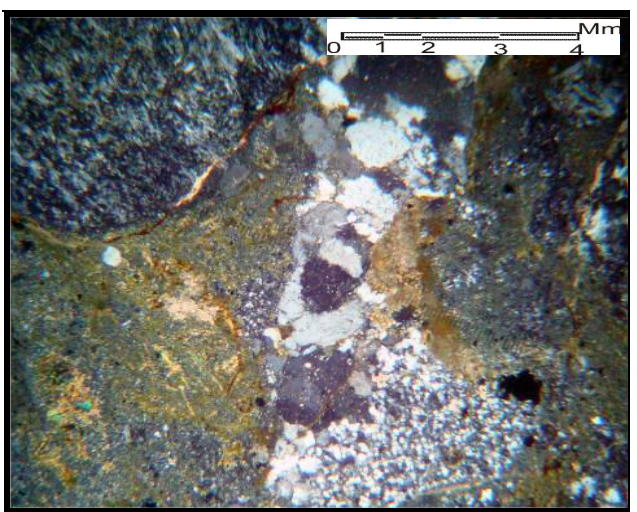

Fig.27: Photomicrograph showing hematite in fractures and Nubian sandstone fragment of quartzitic composition in lithic tuffs, XPL

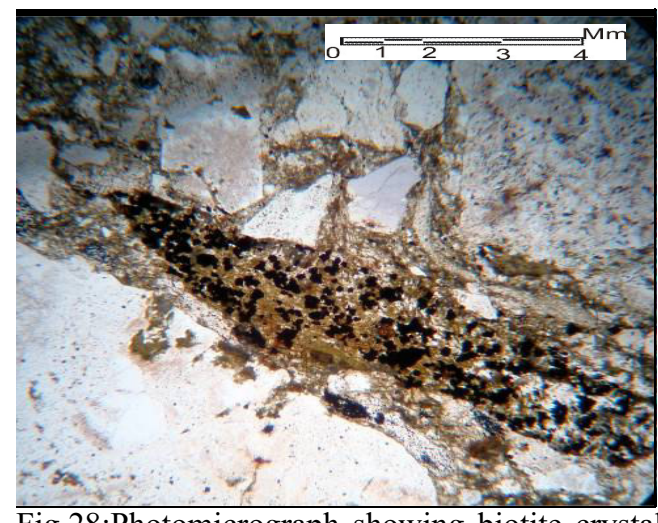

Fig.28:Photomicrograph showing biotite crystal partially replaced by hematite in lithic tuffs, PPL

northwestern parts of the district. It is fairly homogeneous nonporphyritic medium to finegrained. Microscopically, it exhibits hypidiomorphic texture, and composed of antiperthitic plagioclase, perthitic orthoclase, hornblende, arfvedsonite aegirine, quartz. Apatite is the only accessory mineral mainly enclosed in amphiboles.

\section{IRON ORE MINERALS}

The ore microscopic study of the polished surfaces recorded hematite, goethite, magnetite and ilmenite constituting the iron mineralization in the Agib ring complex and the alkali feldspar granite filling the interstitial spaces, rock fractures and replacing quartz, biotite and other silicate minerals. The gangue minerals 
are represented by quartz, orthoclase, plagioclase, arfvedsonite, tourmaline, aegirine-augite, hornblende and sanidine. These rocks hosting the mineralization are characterized by abundant open fillings, replacement of the rock forming minerals, spotted and maculose textures with developed hematite. The quartz gangue mineral forms composite aggregates of cataclastic texture and mosaic habit.

\section{Hematite}

Hematite occurs in a variety of different forms. In the hand specimen, hematite is filling the cracks of Agib ring complex rock units and the interspaces between its crystals as well as replacing the rock forming mineral sites. Hematite is from dark steel gray or iron black in color. It occurs occasionally filling fractures, forming the microveinlets and as fibrous elongated crystals forming augen shape. Its crystals occur either as network of microveinlets and coarse-grained massive structure. The mineral is present also as elongated

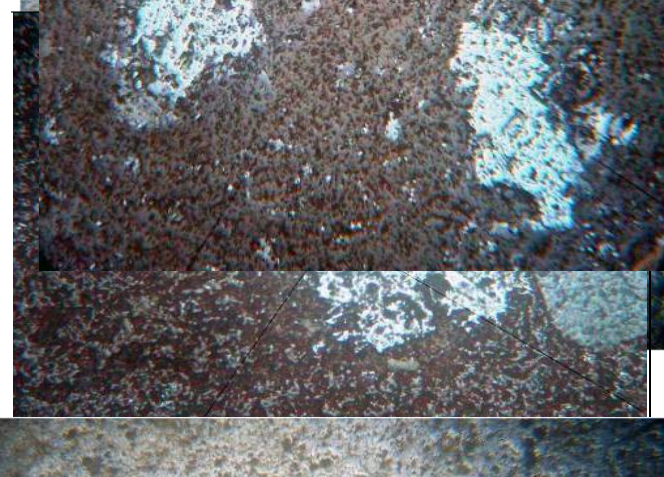

Fig.29: Photomicrograph showing coarse-grained subhedral hematite crystals, quartz syenite, RPL

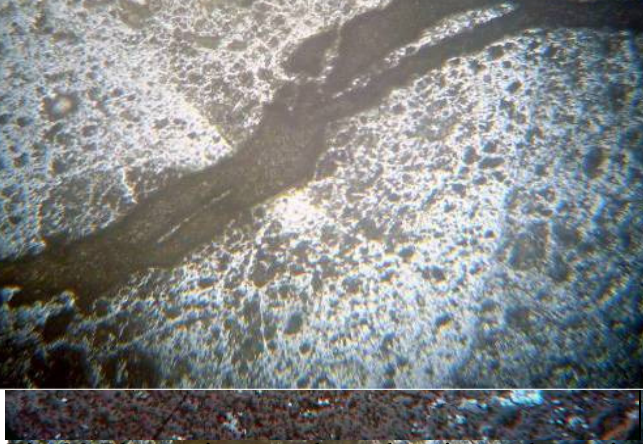

Fig.30:Photomicrograph showing hematite crystals in trachyte rock, RPL

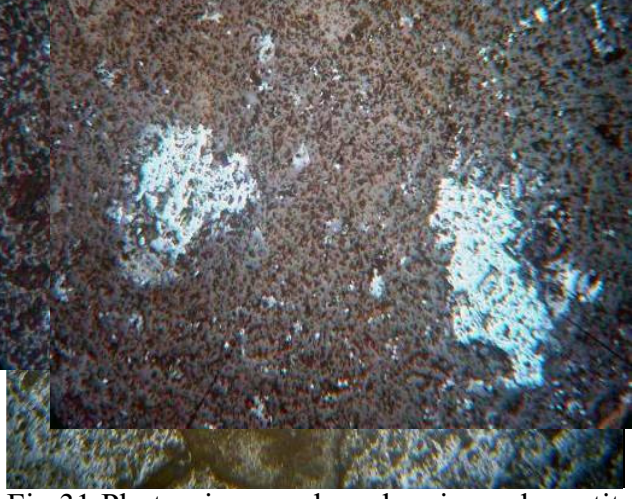

Fig.31:Photomicrograph showing hematite filling microfractures in rhyolite, RPL

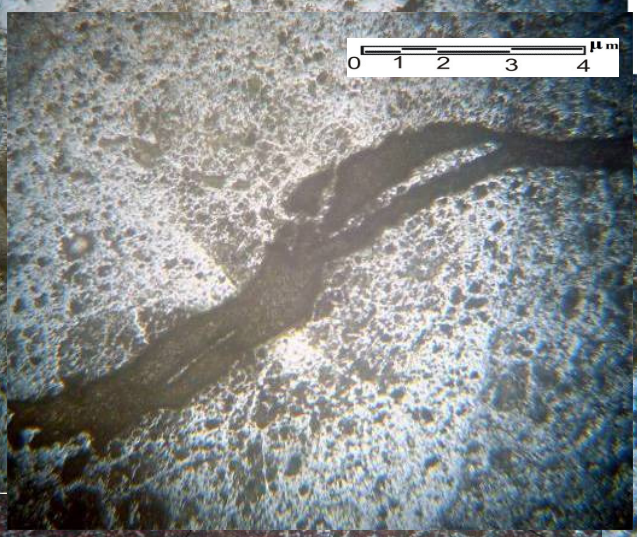

Fig.32:Photomicrograph showing hematite and ilmenite filling microstructures, rhyolite, RPL

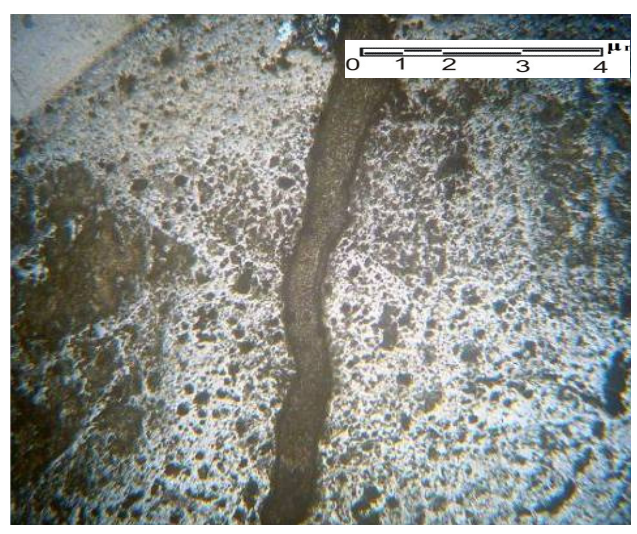

Fig.33:Photomicrograph of polished surface showing hematite and ilmenite filling microstructures, rhyolite rock, RPL 


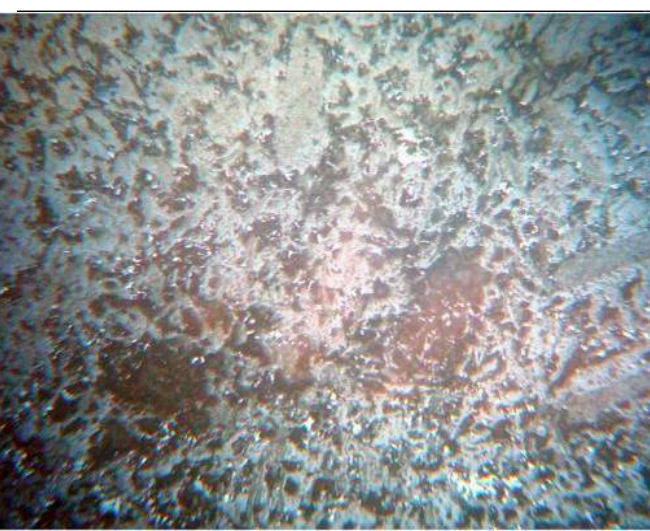

Fig.34:Photomicrograph of hematite ore with abundant quartz and feldspar minerals in rhyolite, RPL

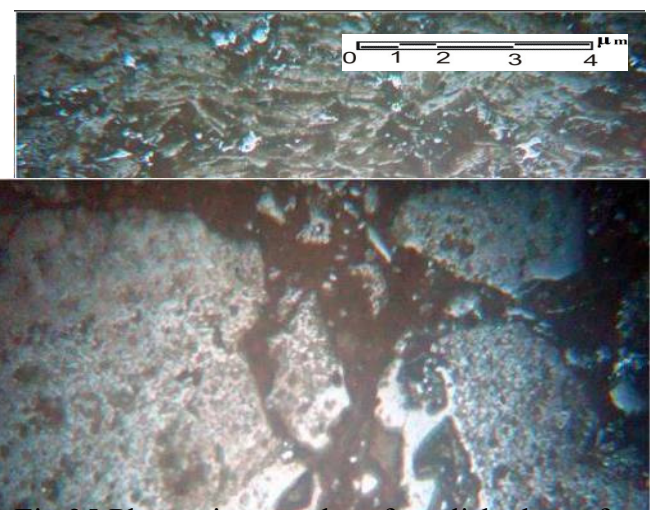

Fig.35:Photomicrograph of polished surface showing hematite fibrous elongated crystals forming trachyiod texture, lithic tuffs, RPL

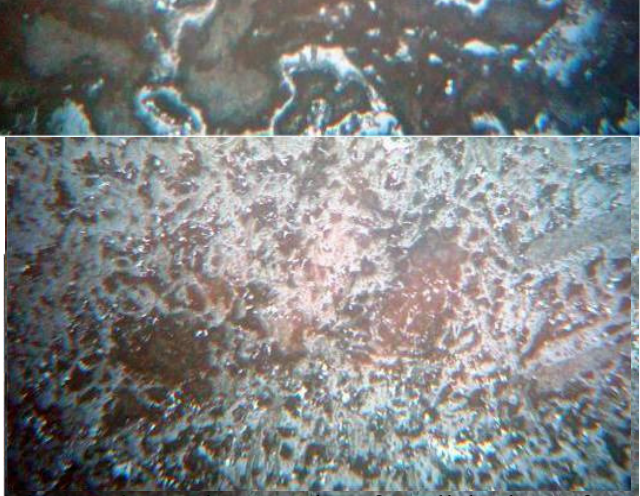

Fig.36:Photomicrograph of polished surface showing hematite network texture, lithic tuffs, RPL

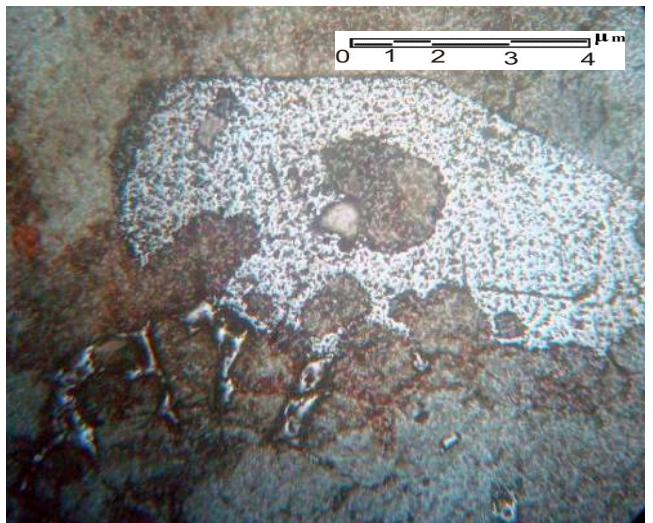

Fig.37:Photomicrograph of a hematite lamellae megacryst with exsolved arfvedsonite along parting planes and abundant mineral inclusions, alkali feldspar granite, RPL

crystals forming lamellar texture that are common in the microveinlets as well as replacing the rock forming minerals. Hematite exhibits moderate relief, parallel and sharp extinction (Figs. 29-37).

\section{Goethite}

Goethite, the iron oxyhydroxide mineral, occurs as massive, aggregate, stock of fracture filling veinlets network and commonly with colloform texture. Goethite is often formed through the oxidation of other iron-rich minerals, and could be formed as a primary mineral in hydrothermal deposits (Figs.38-39).

\section{Magnetite}

Magnetite occurs as euhedral to subhedral crystals different in size even in the same sample, iron-black in color with metallic luster. It occasionally contains very fine-grained inclusions of other mineral constituents. Magnetite is either slightly, strongly or completely martitized. Lath-shaped martitized crystals represent an indication that the mineral deposited at higher temperature in the early stage of mineralization (Ramdohr, 1977). The mineral is isotropic along the twining boundaries and along the deformation forming zones. There is a slight anomalous anisotropism. Internal re- 


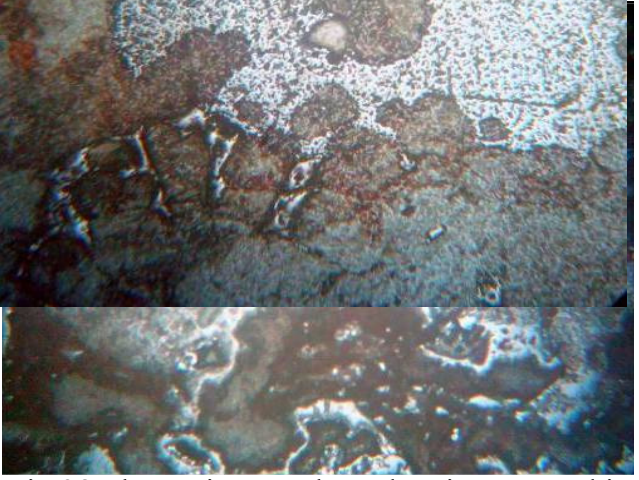

Fig.38:Photomicrograph showing goethite colloform texture in rhyolite, RPL

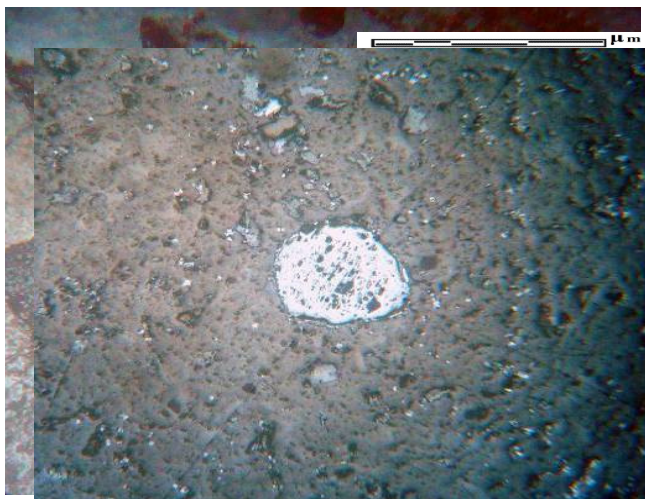

Fig.39:Photomicrograph showing goethite microstructures, filling alkali feldspar granite, RPL

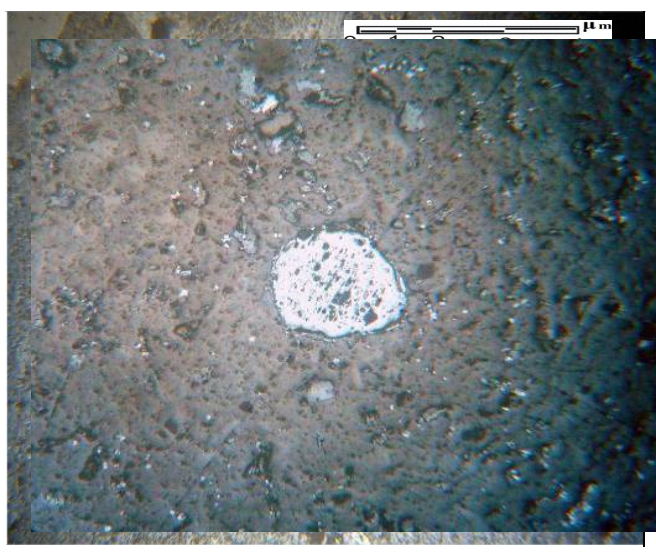

Fig.40:Photomicrograph showing massive magnetite veinlets, quartz syenite, RPL

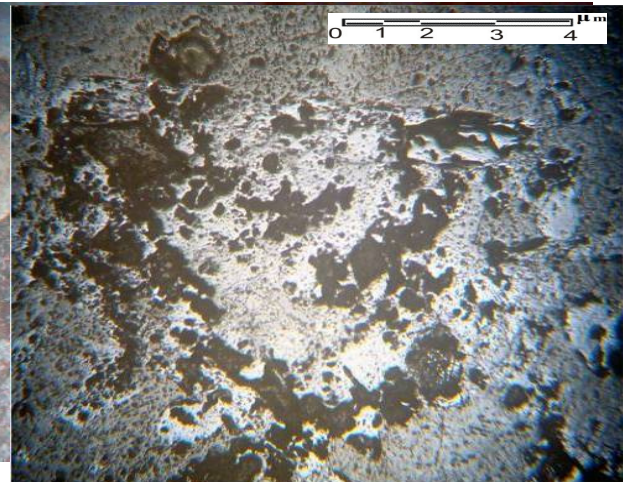

Fig.41:Photomicrograph cubes of magnetite crystals in quartz syenite, RPL

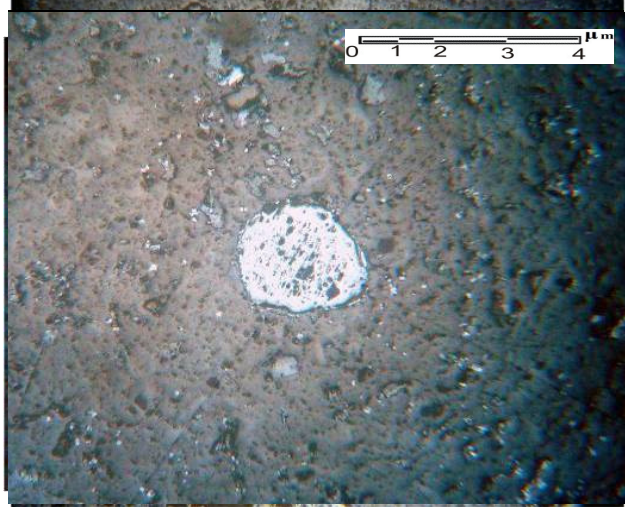

Fig.42:Photomicrograph showing andesite magnetite inclusions, hematite, trachyandesite, RPL

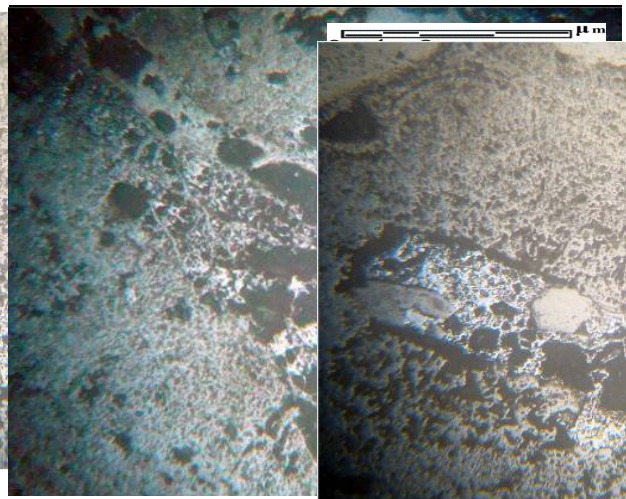

Fig.43:Photomicrograph of partially martitized magnetite ore with black irregular pits, quartz syenite, RPL 
flection is occasionally present in some samples. Magnetite is the principal mineral in the lithic tuffs. It occurs as euhedral, granular subhedral mosaic and anhedral granular masses (Figs. 40-43).

\section{Ilmenite}

Ilmenite exhibits iron-black color with submetallic luster. Under reflected light the mineral is light to dark brown in color. Bire-

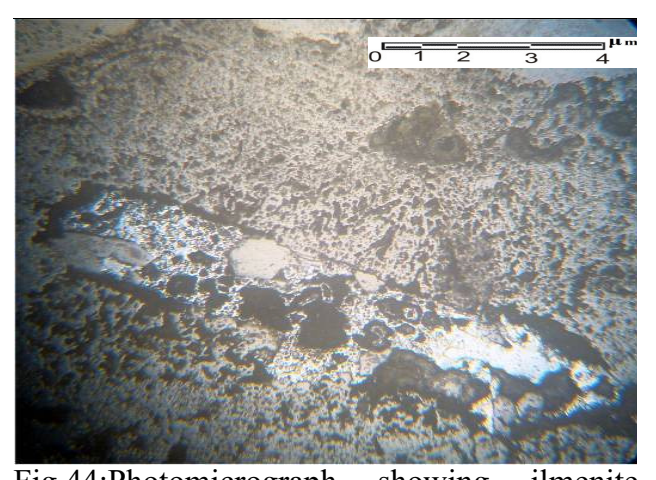

Fig.44:Photomicrograph showing ilmenite crystals in hematite lamellae in rhyolite, RPL flectance is very distinct from light pinkish brown to very dark brown. The mineral is anisotropic; varies in color from light greenish grey to brownish grey. Internal reflections are occasionally recorded in some samples as dark brown color (Figs. 32-44).

Noteworthy mention that none of the martite grains have been observed to contain ilmenite lamellae disposed along the cleavage planes of the pre-existing magnetite. The lack of such lamellae is considered by Buddington and Lindsley, (1964) an indication that the magnetite initially contained only rare amount of titanium, likely derived from the felsic plutonic and metamorphic rocks which are dominant in the studied district.

The study of some of the ore samples of the Agib ring complex rock units, using scanning electron microscope recorded the presence of hematite, magnetite and ilmenite. Hematite is recorded in the quartz syenite, trachyandesite and alkali feldspar granite; ilmenite in the

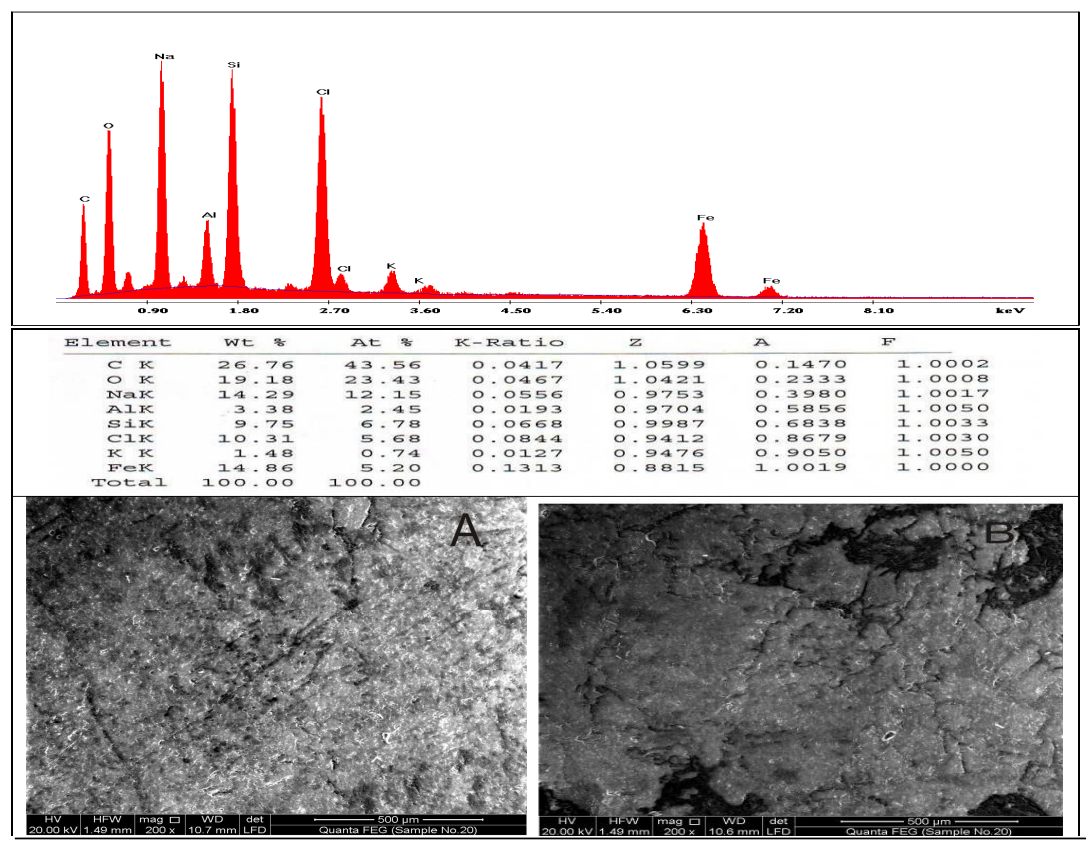

Fig.45:X-ray spectrum analysis of hematite showing high peaks of $\mathrm{Fe}, \mathrm{O}, \mathrm{Si}, \mathrm{Na}$, $\mathrm{Cl}, \mathrm{C}$ and $\mathrm{Al}$ of hematite grains. The scan image shows the hematite crystals filling microfissures within the quartz syenite 


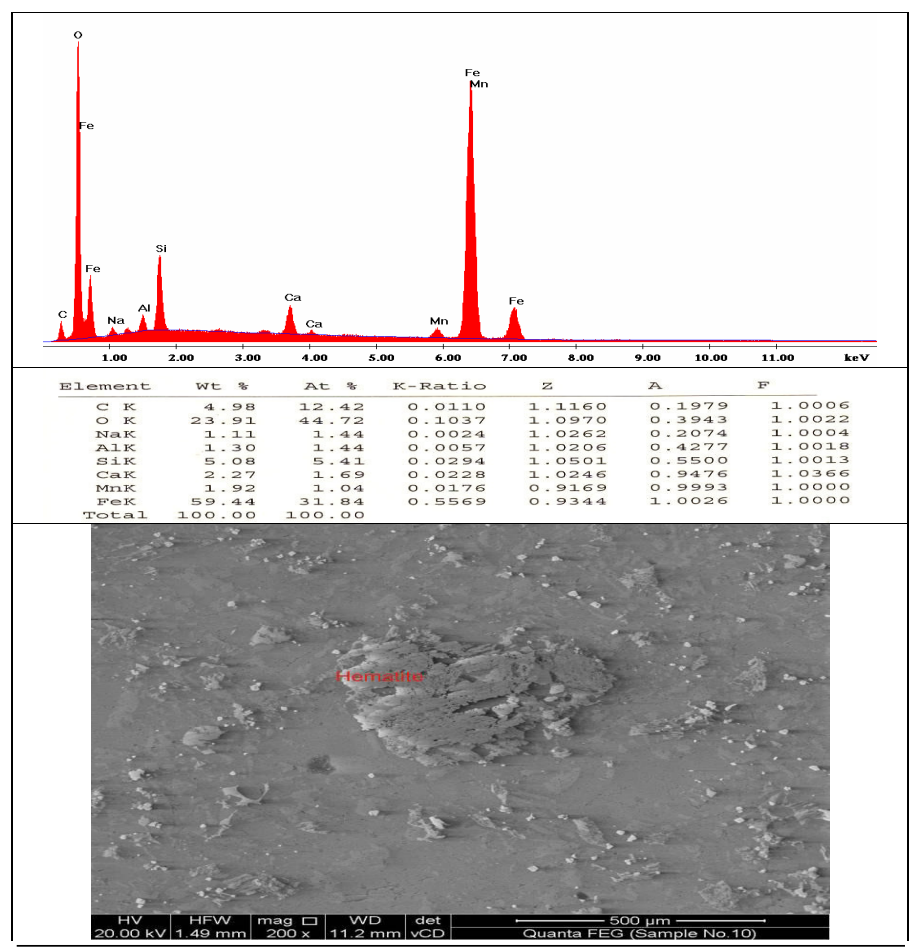

Fig.46:X-ray spectrum analysis of hematite showing high peaks of $\mathrm{Fe}, \mathrm{O}, \mathrm{Ca}, \mathrm{Mn}$ and $\mathrm{Si}$ of hematite grains. The scan image shows the hematite crystals filling microfissur

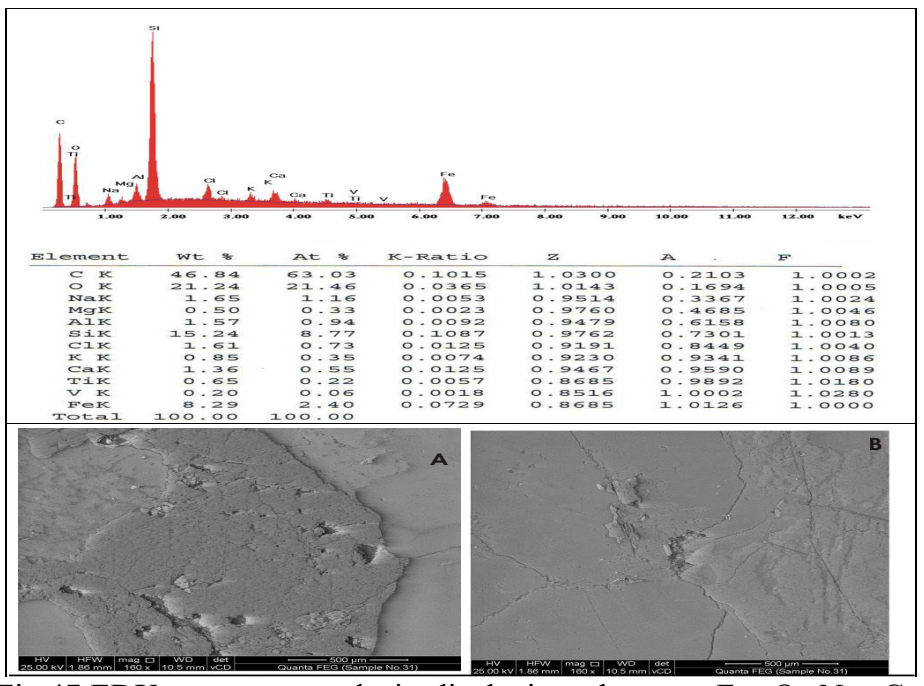

Fig.47:EDX spectrum analysis displaying elements $\mathrm{Fe}, \mathrm{O}, \mathrm{Na}, \mathrm{Ca}$, $\mathrm{Si}$ and recording hematite in the alkali feldspar granite. Scanning photographs showing hematite filling cracks 


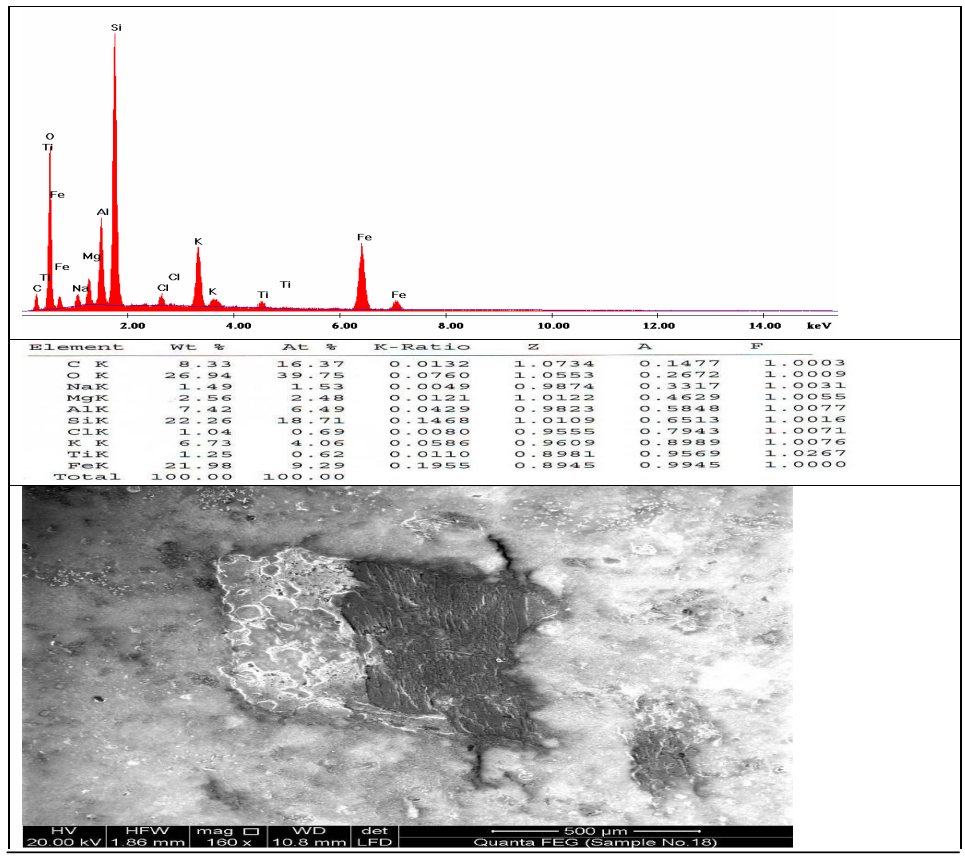

Fig.48: EDX analysis displaying elements $\mathrm{Fe}, \mathrm{Ti}, \mathrm{Al}, \mathrm{Si}, \mathrm{O}$ and recording magnetite in lithic tuffs. Scanning photograph showing hematite crystals in lithic tuffs

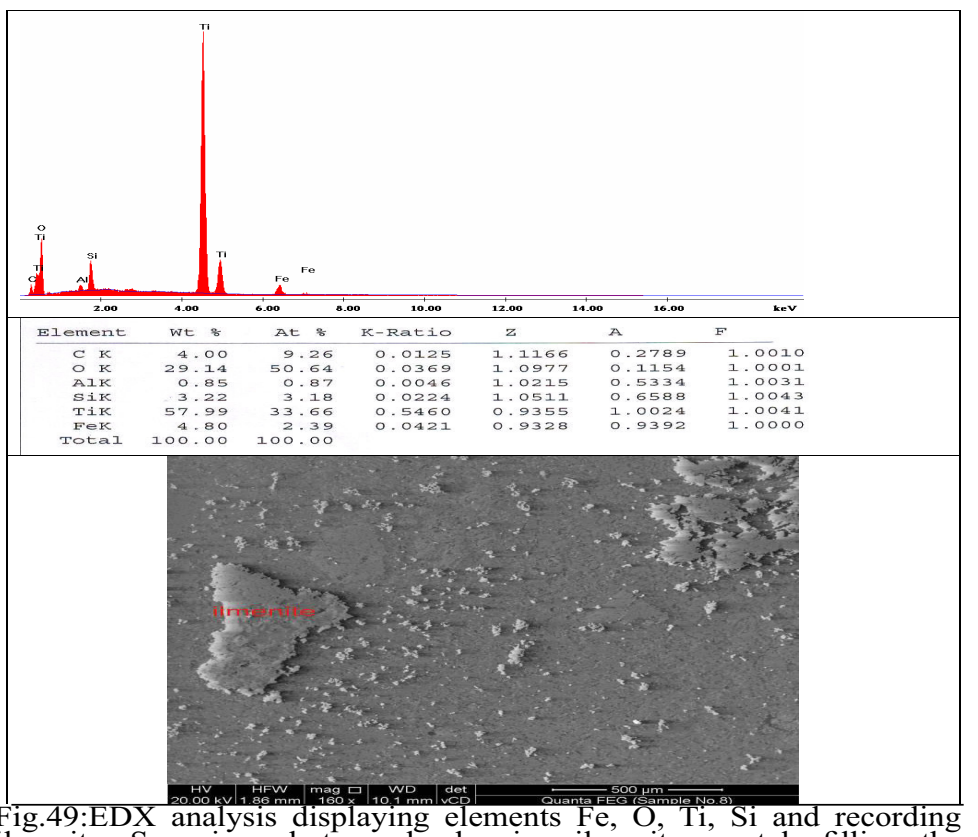

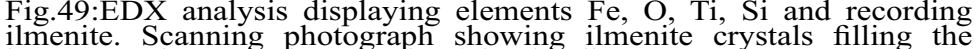
interspaces between the crystals of the rhyolites 
porphyritic rhyolite and magnetite in the lithic tuffs (Figs.45-49). SEM studies show that the color gradations reflect either differences in grain size of individual hematite crystals or differences in size and dense crystal aggregates.

\section{URANIUM IN RELATION TO IRON MINERALIZATION}

El-Afandy (2003) recorded $U$ and Th in 24 samples of Agib ring complex rock units. Both elements display gradual increase from the trachyandesite (up to $1.79 \mathrm{ppm}$ and $7.55 \mathrm{ppm}$ ), the alkali granites (up to $7.23 \mathrm{ppm}$ and $27.33 \mathrm{ppm}$ ) respectively via the rhyolites and alkali quartz syenites. Uranium content increases with increase of Th, $\mathrm{Rb}, \mathrm{Zr}, \mathrm{Ga}, \mathrm{Y}$ and total REE contents indicating magmatic fractionation forming co-magmatic series. These increasing trends point to that $\mathrm{U}$ might be of magmatic origin. El-Afandy (Op.Cit) referred these positive correlation that $\mathrm{U}$ and $\mathrm{Th}$ are hosted in specific refractory minerals during crystallization, especially zircon, sphene and postmagmatic hydrothermal iron oxides. However, the recorded iron minerals in these rock units in which iron oxide content is the highest $(9.37$ to $7.20 \%)$ in the trachyandes-

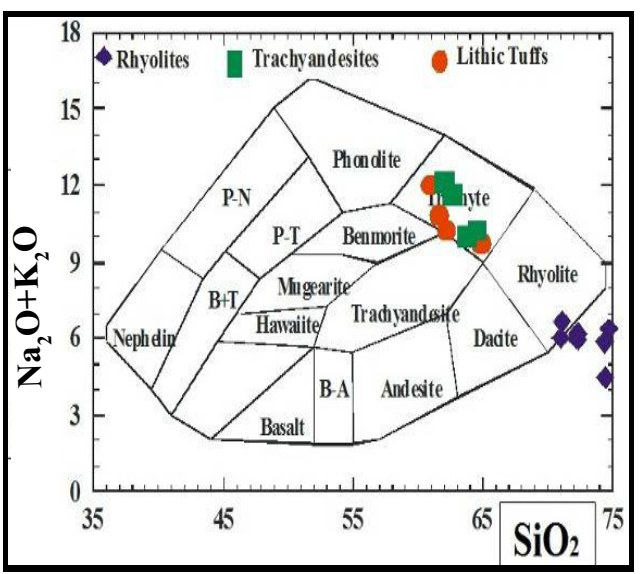

Fig.50: $\mathrm{SiO}_{2}-\left(\mathrm{Na}_{2} \mathrm{O}+\mathrm{K}_{2} \mathrm{O}\right)$ binary diagram for the rhyolite, trachyandesite and lithic tuffs (Cox et al., 1979). ites, lithic tuffs (7.8 to $7.01 \%$ ) quartz syenite $(7.93-4.94 \%)$ and the least in rhyolites $(4.38$ to $1.53 \%)$. The occasional increase of $U$ and Th contents is most probably related to the increase of the iron ore minerals in such rock types and not the silicate minerals. This most probably reflects its leaching from such Ubearing silicate minerals to be adsorbed onto the iron ore minerals.

\section{GEOCHEMICAL CHARACTERIZATION}

The studied rock units have been classified petrographically into rhyolite, trachyandesite, lithic tuffs, quartz syenite and alkali feldspar granite (Figs. 50-54). The ranges of chemical components of 25 analyses of these rock units are given in Table 1. Geochemically, on the total alkali-silica diagram of Cox et al.(1979) the data points of rhyolite fall in and outside the rhyolite field because of excess $\mathrm{SiO}_{2}$ content. The trachyandesite and lithic tuffs plot in the trachyte field. On Middlemost total alkalisilica diagram (1994), the quartz syenite samples except one fall in syenite field and the alkali feldspar granite samples fall in the quartz monzonite field. All samples are evolved towards silica oversaturated magma.

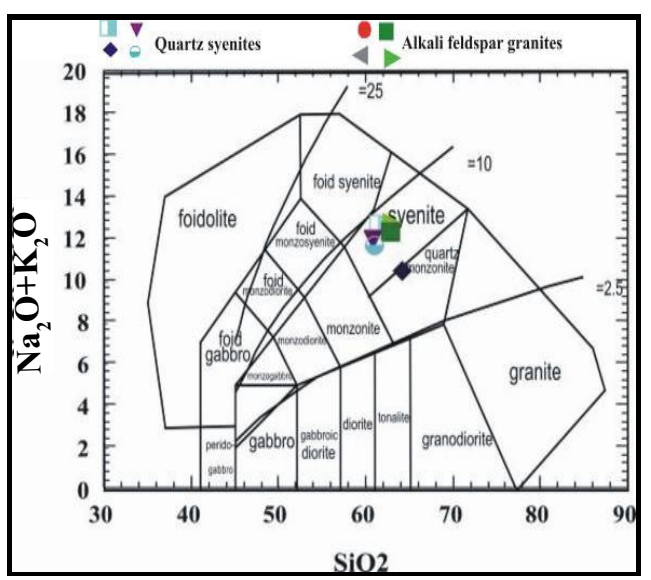

Fig.51 : Chemical nomenclature of plutonic rocks using TAS diagram (Middlemost 1994). 
Table 1 : Ranges of chemical components of Gabal Agib Ring Complex, Southeastern Desert, Egypt

\begin{tabular}{|c|c|c|c|c|c|c|c|c|c|c|}
\hline Sp.No. & $1 \mathbf{A G}$ & 2AG & 3AG & $4^{*} \mathrm{AG}$ & 5AG & 6AG & 7AG & 8AG & 9AG & 10AG \\
\hline $\begin{array}{l}\text { Rock } \\
\text { Type }\end{array}$ & \multicolumn{2}{|c|}{ Rhyolite } & \multicolumn{2}{|c|}{ Trachyandesite } & \multicolumn{2}{|c|}{ Lithic Tuffs } & \multicolumn{2}{|c|}{ Quartz syenite } & \multicolumn{2}{|c|}{$\begin{array}{r}\text { Alkali feldspar } \\
\text { granite }\end{array}$} \\
\hline $\mathrm{SiO}_{2}$ & 70.88 & 70.02 & 60.78 & 60.89 & 64.60 & 64.49 & 64.26 & 60.91 & 64.21 & 64.05 \\
\hline $\mathrm{Al}_{2} \mathrm{O}_{3}$ & 13.49 & 15.30 & 15.23 & 15.52 & 15.11 & 16.35 & 16.04 & 12.36 & 14.02 & 14.48 \\
\hline $\mathrm{TiO}_{2}$ & $\mathbf{0 . 3 3}$ & 0.34 & 0.65 & $\mathbf{0 . 5 3}$ & 0.80 & 0.36 & 0.91 & 0.38 & 0.63 & 0.51 \\
\hline MnO & 0.1 & 0.06 & 0.41 & 0.19 & 0.23 & 0.17 & 0.25 & 0.16 & 0.19 & 0.17 \\
\hline $\mathrm{Fe}_{2} \mathrm{O}_{3}{ }^{*}$ & 3.53 & 3.51 & 6.37 & 6.08 & 7.80 & 7.01 & 7.93 & 7.75 & 5.25 & 5.00 \\
\hline MgO & 0.05 & 0.06 & 0.41 & 0.29 & 0.16 & 0.12 & 0.13 & 0.27 & 0.33 & 0.18 \\
\hline $\mathrm{CaO}$ & 0.32 & 0.29 & 1.23 & 1.82 & 1.03 & 1.18 & 1.32 & 0.84 & 0.12 & 0.73 \\
\hline $\mathrm{Na}_{2} \mathrm{O}$ & 0.16 & 0.12 & 6.50 & 6.70 & 6.22 & 6.46 & 6.40 & 6.20 & 6.57 & 7.60 \\
\hline $\mathrm{K}_{2} \mathrm{O}$ & 5.96 & 5.36 & 5.72 & 5.24 & 1.81 & 1.77 & 1.30 & 5.19 & 5.74 & 5.23 \\
\hline $\mathbf{P}_{2} \mathbf{O}_{5}$ & 0.04 & 0.02 & 0.2 & 0.08 & 0.24 & 0.18 & 0.26 & 0.06 & 0.21 & 0.16 \\
\hline LOI & 5.04 & 4.90 & 2.40 & 25.0 & 1.30 & 1.01 & 0.90 & 5.2 & 1.90 & 1.30 \\
\hline Total & 99.90 & 99.98 & 99.90 & 99.84 & 99.3 & 99.10 & 99.70 & 99.32 & 99.17 & 99.41 \\
\hline \multicolumn{11}{|c|}{ Trace elements (ppm) } \\
\hline $\mathrm{Cr}$ & 16 & 10 & 32 & 9 & 28 & 20 & 15 & 8 & 15 & 11 \\
\hline $\mathbf{N i}$ & 5 & 2 & & & 9 & 3 & 5 & 4 & 4 & 2 \\
\hline $\mathrm{Cu}$ & 17 & 4 & 13 & 7 & 12 & 5 & 14 & 10 & 13 & 12 \\
\hline $\mathbf{Z n}$ & 51 & 17 & 581 & 89 & 225 & 74 & 162 & $\mathbf{8 3}$ & 170 & 143 \\
\hline $\mathbf{Z r}$ & 607 & 428 & 1233 & 954 & 1.631 & 1002 & 1247 & 493 & 793 & 742 \\
\hline $\mathbf{R b}$ & 96 & 10 & 77 & 43 & 98 & 69 & 132 & 75 & 72 & 65 \\
\hline $\mathbf{Y}$ & 243 & 172 & 486 & 375 & 651 & 394 & 498 & 201 & 317 & 277 \\
\hline Ba & 4143 & 2581 & 4594 & 2189 & 2421 & 498 & 6236 & 2300 & 4574 & 3700 \\
\hline $\mathbf{P b}$ & 25 & 10 & 35 & 11 & 33 & 11 & 10 & 32 & 24 & 17 \\
\hline $\mathrm{Sr}$ & 2224 & 1571 & 4551 & 3495 & 6146 & 3699 & 4601 & 1847 & 2954 & 2604 \\
\hline $\mathbf{G a}$ & 30 & 10 & 26 & 14 & 26 & 23 & 30 & 10 & 26 & 14 \\
\hline V & 77 & 22 & 73 & 39 & 42 & 33 & 77 & 22 & 73 & 39 \\
\hline Nb & 240 & 146 & 183 & 73 & 116 & 102 & 240 & 146 & 183 & 73 \\
\hline
\end{tabular}

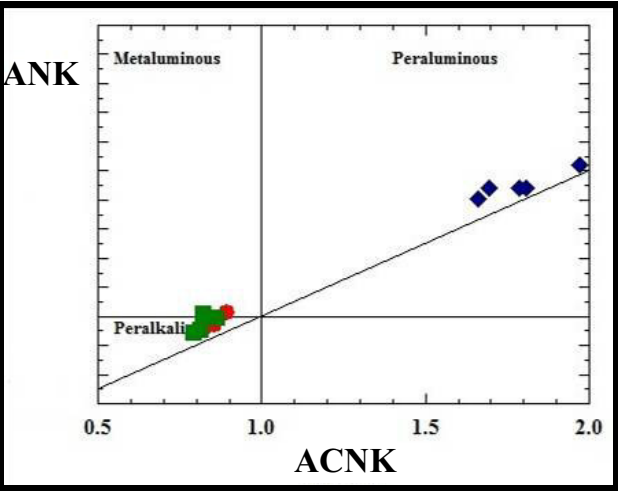

Fig.52:ANK-ACNK variation diagram for the quartz rhyolite, trachyandesite and lithic tuffs (Maniar and Piccoli, 1989). Symbols as in Fig.50

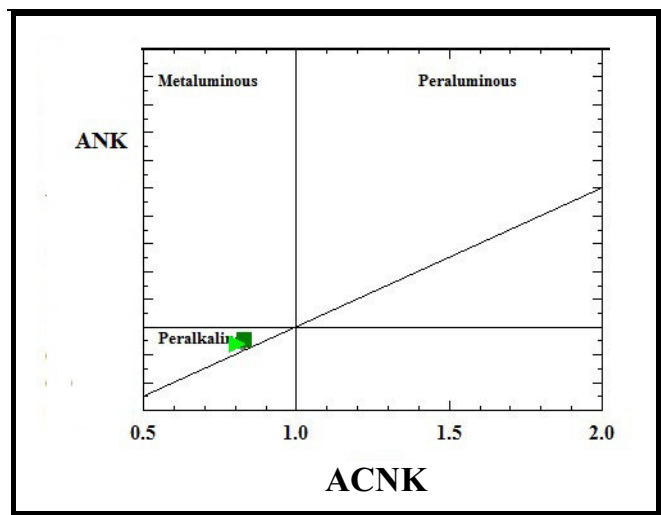

Fig.53:ANK-ACNK variation diagram for the quartz syenite and alkali feldspar granite (Maniar and Piccoli, 1989). Symbols as in Fig.50 


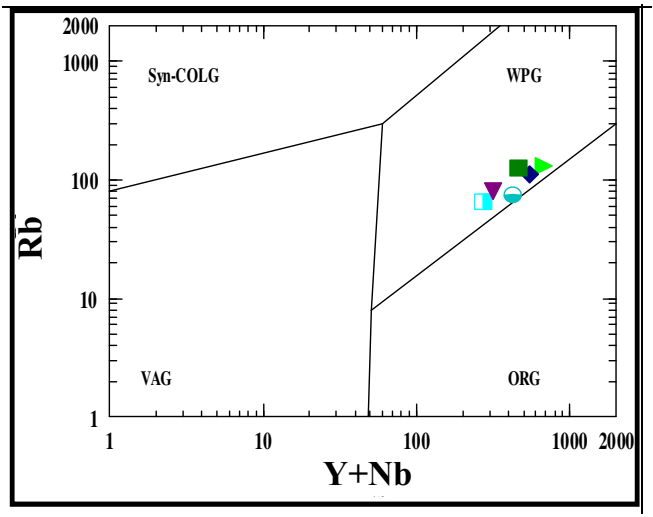

Fig.54:Plots of $(\mathrm{Nb}+\mathrm{Y})-\mathrm{Rb}$ binary discriminating diagrams showing the tectonic setting of the investigated alkali feldspar granite (Pearce et al., 1984). Symbols as in Fig.50

On the $\mathrm{Al}_{2} \mathrm{O}_{3} /\left(\mathrm{Na}_{2} \mathrm{O}+\mathrm{K}_{2} \mathrm{O}\right)$ versus $\mathrm{Al}_{2} \mathrm{O}_{3} /$ $\left(\mathrm{CaO}+\mathrm{Na}_{2} \mathrm{O}+\mathrm{K}_{2} \mathrm{O}\right)$ diagram of Maniar and Piccoli (1989) the rhyolite exhibits peraluminous nature, while quartz syenite, trachyandesite, lithic tuffs, and the alkali feldspar granite are of peralkaline nature.

On $\mathrm{Y}$ versus samples $\mathrm{Nb}$ and $\mathrm{Rb}$ versus $\mathrm{Y}+\mathrm{Nb}$ diagrams of Pearce et al. (1984), all the alkali feldspar granite and the quartz syenite samples fall in the WPG field.

\section{CONCLUSION}

1- The studied Agib Ring Complex comprises well developed outer ring of alkali rhyolite porphyry and quartz syenite core. Trachytes and their pyroclastic equivalents forming roof pendants and rafts represent the remnants of volcanic cone. The rocks of Agib ring complex derived from peralkaline mag$\mathrm{ma}$ in within plate tectonic setting.

2-The iron mineralization in Agib ring complex is in the form of disseminated crystals, skeleton like crystals filling the fractures, replacement of the rock forming minerals and staining of hematite. The recorded ore mineral constituents in Agib ring com- plex rock units, are hematite, magnetite, goethite and ilmenite.

3-The mode of occurrence as well as the ore minerals constituents point to the hydrothermal origin of the iron mineralization in the rock units of Agib ring complex.

\section{REFERENCES}

Agha, A., 2007. Geology and geochemistry of Gabal Agib Ring Complex, Southern Eastern Desert, Egypt. Thesis Fac. Sci., Cairo Univ., El-Fayoum Branch., Egypt.

Buddington, A.F. and Lindsley, D.H., 1964. Iron-titanium oxide minerals and synthetice equivalents. J. Petrol., 5, 310-35

Cox,K.G.; Bell,J.D., and Pankhurst,R. J.,1979. The interpretation of igneous rocks.London,Allen and Unwine,450p.

El-Afandy, A.H., 2003. Geology, Geochemistry and radioactivity of Gabal Agib ring complex, Southeastern Desert, Egypt. Egypt. Mineral., 15,185-212.

Maniar, P.A. and Piccoli, P.M., 1989. Tectonic discrimination of granitoids. Ball. Geol. Soc. Am., 101, 635643.

Middlemost, E.A.K., 1994. Naming materials in the magma / igneous rock system. Earth- Sci. Reviews, 37, 215 224.

Pearce, J.A.; Harris, N.B.W. and Tindle, A.J., 1984. Trace element discrimination diagrams for the tectonic interpretation of granitic rocks. J. Petrol., $25,956-983$

Ramdohr, P., 1977. Die Erzmineralien und Ihre Verwachsungen. Akademi Verlag, Berlin, 1277s. 
دراسـات عن تمعدنات الحديد في معقد جبل عجيب الحلقي ، جنوب الصحراء الثرقية ، مصر

محمود محمد حسان و عادل حسن الافندي وحاتم محمد الدسوقي وحسن محمد عسر ان وعمر عبدالعزيز سليمان

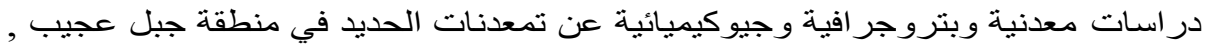

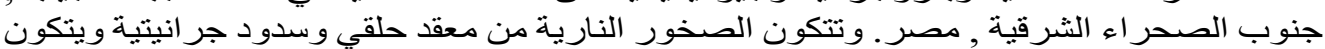

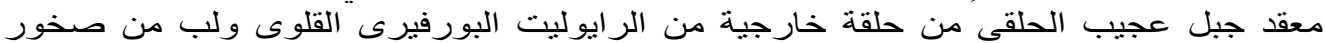
الكوارتز سيانيت. تمثل صخور التراكيت وما يقابلها من الصخور الفتانتاتية الحرارية بقايا المخروط

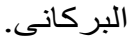

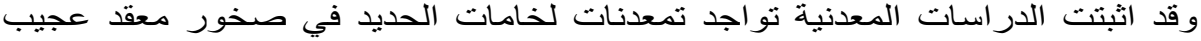
الحلقي وتم تسجيل معدن الهيماتيت ومعدن الجوثيت و المجنيتيت و إليمنيت. وتنتو اجد تمعدنات الحديد

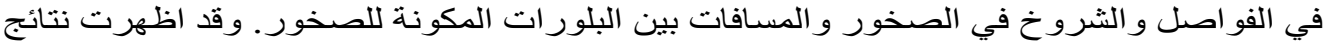

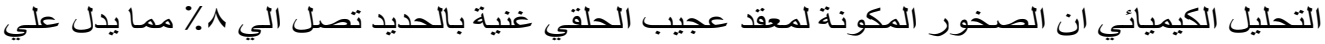
ان الصخور تعرضت الي نشاط محاليل حرمائية ونتج عنها ترسيب لمعادن الحديد في الفواصل الصل والثروخ وحول البلور ات في الصخور. 